\title{
Evaluation of Allelopathic Effect of White Lupin (Lupinus termis L.) Leaf Extract on the Biochemical Dynamics of Common Purslane (Portulaca oleracea L.)
}

\author{
H. M. El-Shora and A. M. Abd El-Gawad \\ Botany department, Faculty of Science, Mansoura University, \\ Mansoura, 35516, Egypt.
}

\begin{abstract}
ALELOPATHY has become a much more important phenomenon in biological control method of weeds in any kind of agricultural practices. So, the present study has been carried out to evaluate the allelopathic influence of the Lupinus leaf extract on biochemical constituents and enzymatic activities of the Portulaca oleracea L. plant. The obtained results indicate that induction of calmodulin ( $\mathrm{CaM})$, abscisic acid (ABA) and indole acetic acid (IAA) levels in the $P$. oleracea plant under the effect of Lupinus leaf extract. Also, seed germination, total soluble sugars, total lipids, total amino acids and total protein contents were reduced in P. oleracea under treatment with Lupinus leaf extract. The extract induced the activities of both $\alpha$-amylase and IAA oxidase but inhibited the activities of nitrate reductase (EC, 1.7.1.3), glutamine synthetase (EC, 6.3.1.2) and pyruvate dehydrogenase (EC, 1.2.4.1). Thus, allelopathic extract of the L. termis may be used as eco-friendly natural herbicide for management of the $P$. oleracea.

Keywords: Allelopathy, Calmodulin, Abscisic acid, Indole acetic acid,
\end{abstract} Lupinus termis, Portulaca oleracea.

Allelopathy is a valuable source for natural herbicides discovery, as many allelochemicals exhibit phytotoxic effects against weeds (D'Abrosca et al., 2013). Knowing the effects of a chemical on plant metabolism (receiving plant) is very important both in order to suggest its role in a natural context. The allelopathic effect on the germination and seedling growth of various plant species (both weeds and crops) have been investigated (El-Rokiek and Eid 2009), while few studies deal with the effect on plant metabolism (Weir et al., 2004; Hussain et al., 2010; Gürsoy et al., 2012; Ullah et al., 2013). It plays an important role in the evolution of plant communities, exotic plant invasion and replant failure (Inderjit 2003). The impact of weed allelochemicals on crops has been studied, however some crops characterized by its allelopathic effect against weeds (Maqbool et al., 2013). The residues of allelopathic crops bear a great potential in suppressing weeds (Singh et al., 2003). Allelopathy of crops is considered as one of the most successful tool to manage weed infestations in agricultural production, if it can be exploited appropriately in a rotational cropping system (Khanh et al., 2007).

Corresponding author: E. mail: dgawad84@mans.edu.eg

Tel. (+2) 01003438980, Fax: (+2) 0502246781 
The allelochemicals are derived into the rhizosphere by process such as leaching from the aerial plant parts, volatile emissions, root exudation and the breakdown of plant residues (Bertin et al., 2003). The use of allelochemicals is being encouraged to utilize this up tapped resource for weed control thereby reducing the ecological, environmental and health problems associated with synthetic pesticides (Cheema et al., 2013; Gürsoy et al., 2013).

The allelochemicals are released largely by plant residues that are left in the fields after the harvest of a crop or through use of cover crops. The strategy for using allelopathy for weed management could be either through directly exploiting natural allelopathic interactions or using biohebicide (allelochemicals). To achieve consistent results in the field from the use of crop residues, it is important to understand the mechanism of allelopathy (Weston and Duke, 2003; Gürsoy et al., 2013).

Allelopathic inhibition involved interaction of different classes of chemicals like phenolic compounds, flavonoids, terpenoids, alkaloids, steroids, carbohydrates and amino acids, with mixtures of different compounds sometimes having a great allelopathic effect than individual compounds alone (James and Bala, 2003; Gürsoy et al., 2013).

Portulaca oleracea $\mathrm{L}$. (Purslane) is a $\mathrm{C}_{3}$ plant and a common troublesome weed worldwide (Miyanishi and Cavers, 1980). The plant is used as herbal plant with wide pharmacological applications including, analgesic, antibiotic, (Yang et al., 2007), antioxidant and anti-inflammatory (Lim and Quah 2007; Gürsoy et al., 2013). Among the bioactive components of $P$. oleracea are hesperidin, caffeic acid (Yang et al., 2007), ferulic acid and p-coumaric acid (Xiang et al., 2005; Cheng et al., 2011). In addition, $P$. oleracea has been reported to be rich in $\alpha$-linolenic acid, $\beta$-carotene (Barbosa-Filho et al., 2008), flavonoids, coumarins (Awad 1994), and monoterpene glycoside (Sakai et al., 1996). Some of these bioactive compounds have been reported to be allelochemicals (Cheema et al., 2002; Gürsoy et al., 2013).

The L. termis is grown in Egypt and it is used as fodder crop and green manure for sandy soils to reclaim new lands. Lupin seeds contain great content of proteins, fibers and carbohydrates and they are used for medical and industrial purposes (Abdel-Monaim et al., 2012). However, the allelopathic activity of Lupinus spp. was poorly investigated up to now (Ferreira and Reinhardt, 2010).

Therefore, the present study aimed to evaluate the allelopathic potentiality of $L$. termis leaves on some physiological parameters of the P. oleracea. These parameters are calmodulin (CaM), indole acetic acid (IAA), abscisic acid (ABA), carbohydrates, proteins, lipids and some key enzymes of metabolism.

Egypt. J. Bot., 54, No. 2 (2014) 


\section{Material and Methods}

\section{Preparation of the L. termis leaf extract}

Washed leaves were dried for $48 \mathrm{hr}$ in $50^{\circ} \mathrm{C}$ and ground to fine powder by grinder. Various concentrations $\left(0.2,0.4,0.6,0.8\right.$ and $\left.1 \mathrm{mg} \mathrm{ml}^{-1}\right)$ were prepared using distilled water and the obtained suspension was filtered twice through Whatman filter paper no 2 for removing the fibers and the distilled water used as control (El-Shora and Abo-Kassem, 2001).

\section{Germination bioassay}

Seeds of the P. oleracea were germinated according to El-Shora and AboKassem (2001). Seeds were surface sterilized in 10\% sodium hypochlorite for 10 min and then soaked in running tap water for $24 \mathrm{hr}$. The seeds were then germinated between paper towels, moistened with distilled water (control) or different extract concentrations of the L. termis in sterilized plastic trays and were covered and incubated in dark at $25{ }^{\circ} \mathrm{C}$ for $72 \mathrm{hr}$. The percentage of germination was then calculated.

\section{Treatment experiment}

The germinated seeds with well-grown $P$. oleracea roots were then supported on plastic bowls containing $0.2 \mathrm{mM} \mathrm{CaCl} 2$ solution and different concentrations of L. tremis leaf extract and vigorously aerated for 7 days (El-Shora and AboKassem, 2001). The experimental design was carried out with three replications.

\section{Estimation of CaM}

Two g of the P. oleracea fresh leaves were ground to fine powder in liquid nitrogen. The powder was homogenized in $2 \mathrm{ml}$ extraction buffer contained 100 $\mathrm{mM}$ Tris, $1 \mathrm{mM} \beta$-mercaptoethanol, $0.20 \mathrm{mM}$ phenylmethylsulfonyl fluoride (PMSF), $100 \mathrm{mM}$ ethylenediamine tetraacetic acid (EDTA) and $30 \mathrm{mM}$ $\mathrm{NaHCO}_{3}, \mathrm{pH}$ 7.5. The extract was incubated at $95^{\circ} \mathrm{C}$ for $3 \mathrm{~min}$ in a water bath. The samples were centrifuged at $10,000 \mathrm{~g}$ for $4 \mathrm{~min}$ at $4^{\circ} \mathrm{C}$ and supernatant was used for $\mathrm{CaM}$ assay. The $\mathrm{CaM}$ content was estimated with Enzyme Immunosorbent Assay (ELISA) according to Zhao et al. (1988).

\section{Estimation of $A B A$}

Two $\mathrm{g}$ of $P$. oleracea fresh leaves were ground to powder in liquid nitrogen. The powder was homogenized in $5 \mathrm{ml}$ extraction solution contained $85 \%$ ethyl alcohol and $2 \mathrm{mM}$ butylated hydroxytoluene (BHT) (Wu et al., 1988). The obtained extract was incubated at $4^{\circ} \mathrm{C}$ in a refrigerator for $4 \mathrm{hr}$ and then centrifuged at $1000 \mathrm{~g}$ for $15 \mathrm{~min}$. The obtained pellet was re-extracted with $2 \mathrm{ml}$ extraction solution and incubated at $4^{\circ} \mathrm{C}$ for $4 \mathrm{hr}$ and centrifuged again as described above. The resultant supernatants were combined and loaded onto a C18 column. Using vacuum evaporation the final extract was dried. The obtained residue was dissolved in $5 \mathrm{ml}$ sample and ABA was estimated using an ELISA according to Wu et al. (1988). 


\section{Estimation of IAA}

IAA content in the $P$. oleracea leaves was determined using Salkowaski reagent as described by Gordon and Weber (1951). Estimation of IAA was made by measuring of the spectroscopic absorbance at $535 \mathrm{~nm}$. The concentration of IAA was calculated by preparing a standard curve from IAA solution and the content of IAA was expressed as $\mu \mathrm{g} \mathrm{IAA} \mathrm{g}^{-1}$ fresh weight.

7. Determination of total protein, total lipid, total soluble sugars and free amino acids

The protein content was determined according to the method of Bradford (1976) with bovine serum albumin (BSA) as standard. Total lipid content was estimated according to AOAC (1990). Total soluble sugar was estimated according to Southgate (1991). Total free amino acid was estimated according to Moor and Stein (1957).

\section{Enzymes extraction}

The frozen leaves of $P$. oleracea $(2 \mathrm{~g})$ were homogenized in $50 \mathrm{ml}$ of prechilled $150 \mathrm{mM}$ phosphate buffer $(\mathrm{pH}$ 7.0) under ice-cold conditions. The homogenates were filtered through four layers of cheesecloth and centrifuged at $10,000 \mathrm{~g}$ for $15 \mathrm{~min}$ at $4^{\circ} \mathrm{C}$. The collected supernatant was stored at $4^{\circ} \mathrm{C}$ for assaying the enzymatic activities (El-Shora and ap Rees 1991).

\section{Enzyme assays}

The $\alpha$-amylase activity was estimated according to Ceska et al. (1969). IAA oxidase was assayed according to Darbyshire (1971). The activity of nitrate reductase (NR) was estimated according to Hageman and Reed (1980). Glutamine synthetase (GS) was assayed according to Rhodes et al. (1975) and pyruvate dehydrogenase (PDH) was measured according to Schwartz and Reed (1970).

\section{Statistical analysis}

All obtained data were subjected to ANOVA and the mean values were separated based on Least Significant Difference (LSD) test at 0.05 statistical probability level using COSTAT 6.3 software.

\section{Results}

1. Effect of the L. termis leaf extract on germination percentage of P. oleracea

The germination percentage of $P$. oleracea was significantly reduced $(\mathrm{P} \leq 0.05)$ by increasing the concentration of $L$. termis leaf extract (Fig. 1). Germination percentage was reduced to about $78.8 \%$ after treatment with the highest concentration $\left(1 \mathrm{mg} \mathrm{ml}^{-1}\right)$ of the $L$. termis extract.

Egypt. J. Bot., 54, No. 2 (2014) 


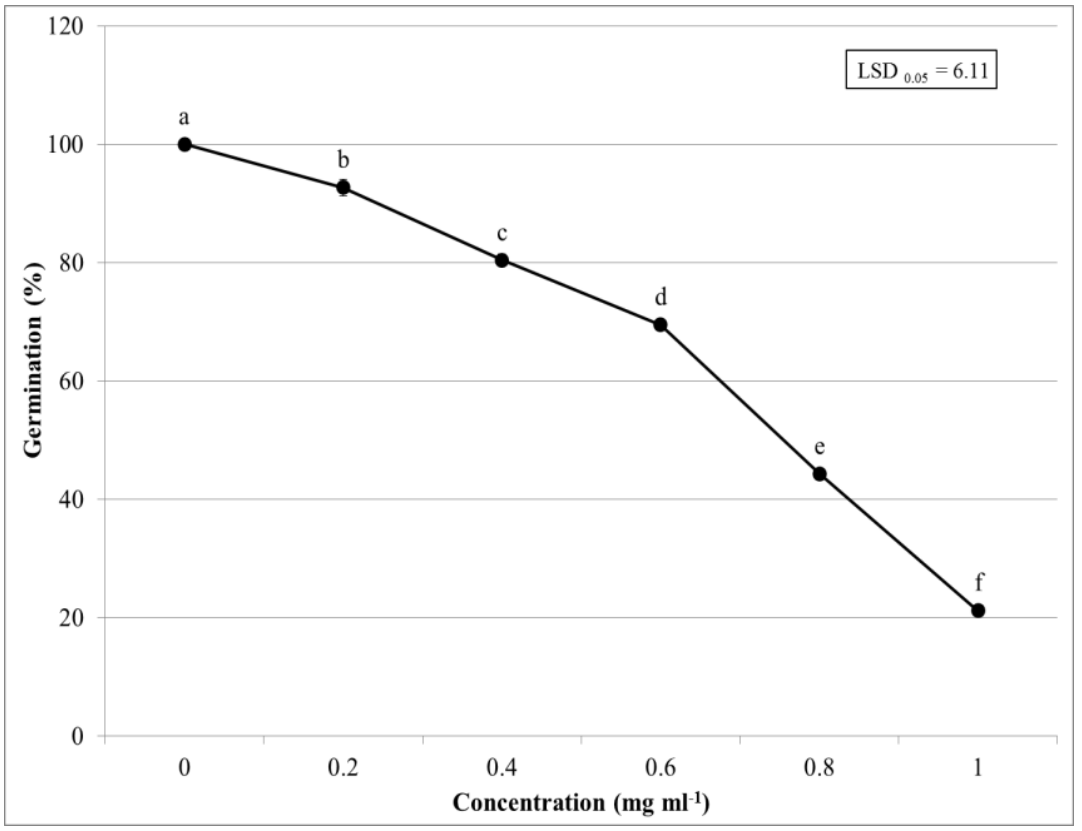

Fig. 1.Effect of Lupinus termis leaf extract on germination of Portulaca oleracea leaves.

2. Effect of the L. termis leaf extract on CaM, ABA and IAA contents of P. oleracea leaves

$\mathrm{CaM}$ content was significantly enhanced $(\mathrm{P} \leq 0.05)$ by the lower concentrations where it is induced by about $112 \%$ at $0.4 \mathrm{mg} \mathrm{ml}^{-1}$ of L. termis extract but it is decreased again by increasing the concentration (Fig. 2).

ABA content in $P$. oleracea leaves was increased significantly $(\mathrm{P} \leq 0.05)$ under treatment with the L. termis extract (Fig. 2), where it is increased to about $613.4 \mathrm{mg} \mathrm{g}^{-1}$ fresh weight at $0.8 \mathrm{mg} \mathrm{ml}^{-1}$. However, the IAA content was decreased gradually and significantly $(\mathrm{p} \leq 0.05)$ to about $46.4 \%$ at the highest concentration $\left(1 \mathrm{mg} \mathrm{ml}^{-1}\right)$.

3. Effect of the L. termis leaf extract on total protein and total lipid in $P$. oleracea leaves

The total protein and total lipid contents were reduced significantly $(\mathrm{P} \leq 0.05)$ in the $P$. oleracea leaves in response to treatment with the L. termis extract (Fig. 3). It is reduced by about $76.8 \%$ and $71.9 \%$, respectively after treatment with $1 \mathrm{mg} \mathrm{ml}^{-1}$ of the L. termis extract. 


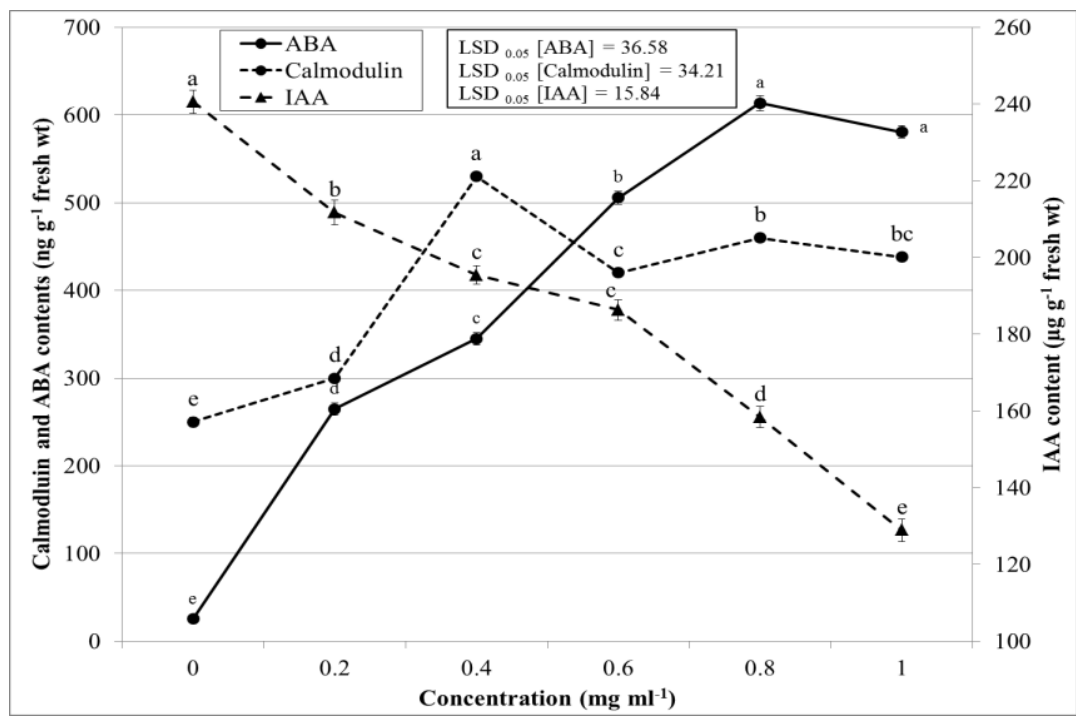

Fig. 2. Effect of Lupinus termis leaf extract on indole acetic acid (IAA), abscisic acid (ABA) and calmodulin (CaM), contents of Portulaca oleracea leaves.

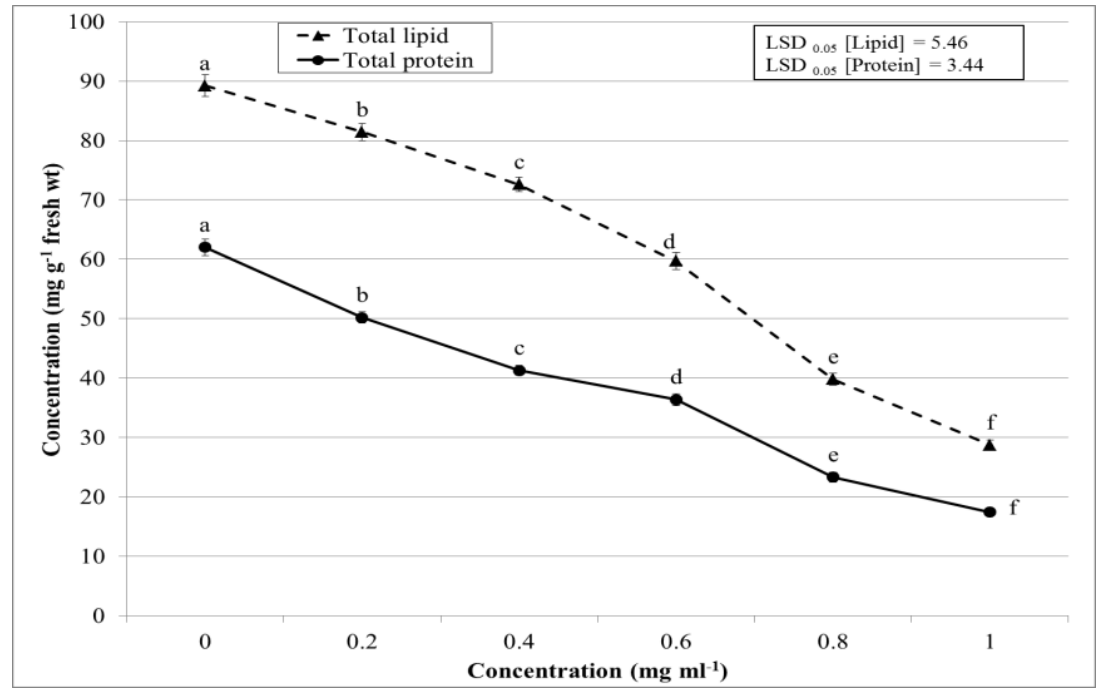

Fig. 3. Effect of Lupinus termis leaf extract on total protein and total lipid of Portulaca oleracea leaves.

4. Effect of L. termis extract on total soluble sugars and total free amino acid in the $P$. oleracea leaves

The content of both total soluble sugars and total free amino acid were increased significantly $(\mathrm{P} \leq 0.05)$ with increasing the concentration of L. termis extract (Fig. 4). Their contents were induced by about $181 \%$ and $375 \%$, respectively.

Egypt. J. Bot., 54, No. 2 (2014) 


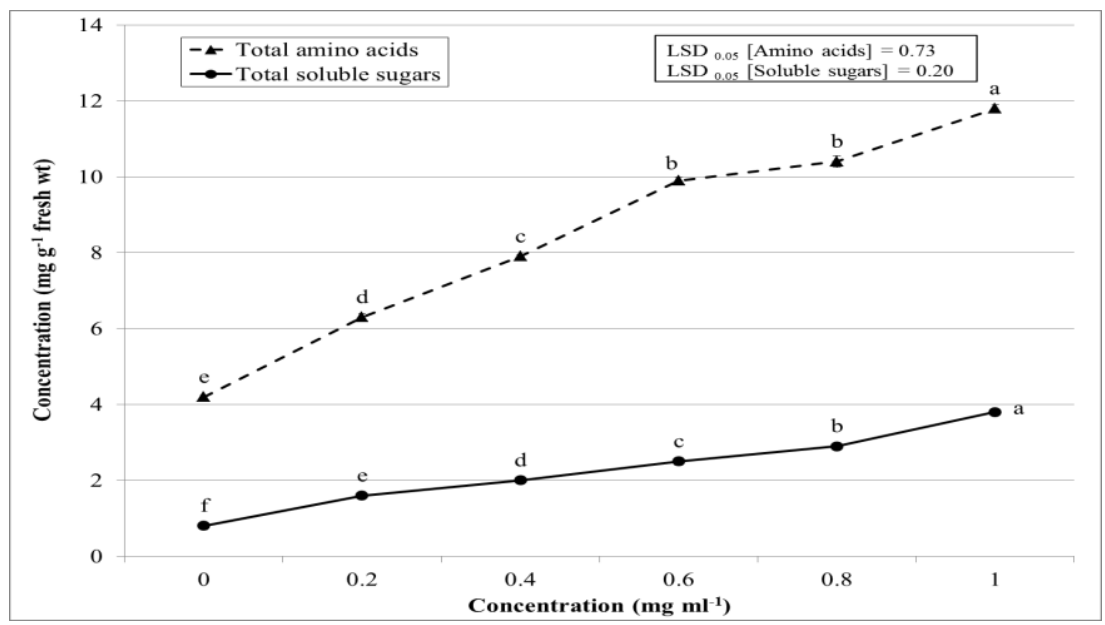

Fig. 4. Effect of Lupinus termis leaf extract on total amino acids and total soluble sugars of Portulaca oleracea leaves.

5. Effect of the L. termis extract on the enzymes activities of P. oleracea leaves

The results indicate that the activities of $\alpha$-amylase and IAA oxidase were enhanced after treatment with the L. termis extract (Fig. 5), where it increased by about $79.4 \%$ and $92 \%$, respectively. On the other hand, the activities of NR, GS and $\mathrm{PDH}$ were significantly inhibited $(\mathrm{P} \leq 0.05)$ by about $69.2 \%, 57.5 \%$ and $83.8 \%$, respectively by $1 \mathrm{mg} \mathrm{ml}^{-1}$ of $L$. termis leaf extract (Fig. 6).

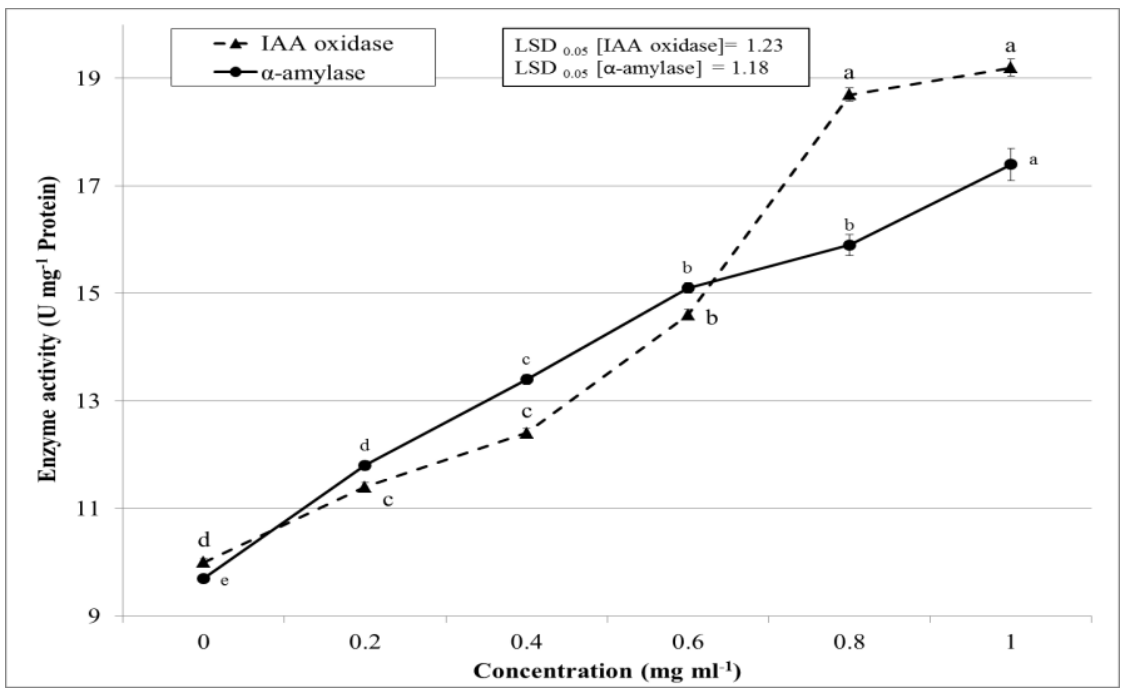

Fig. 5. Effect of Lupinus termis leaf extract on indole acetic acid oxidase (IAA oxidase) and $\alpha$-amylase activities of Portulaca oleracea leaves. 


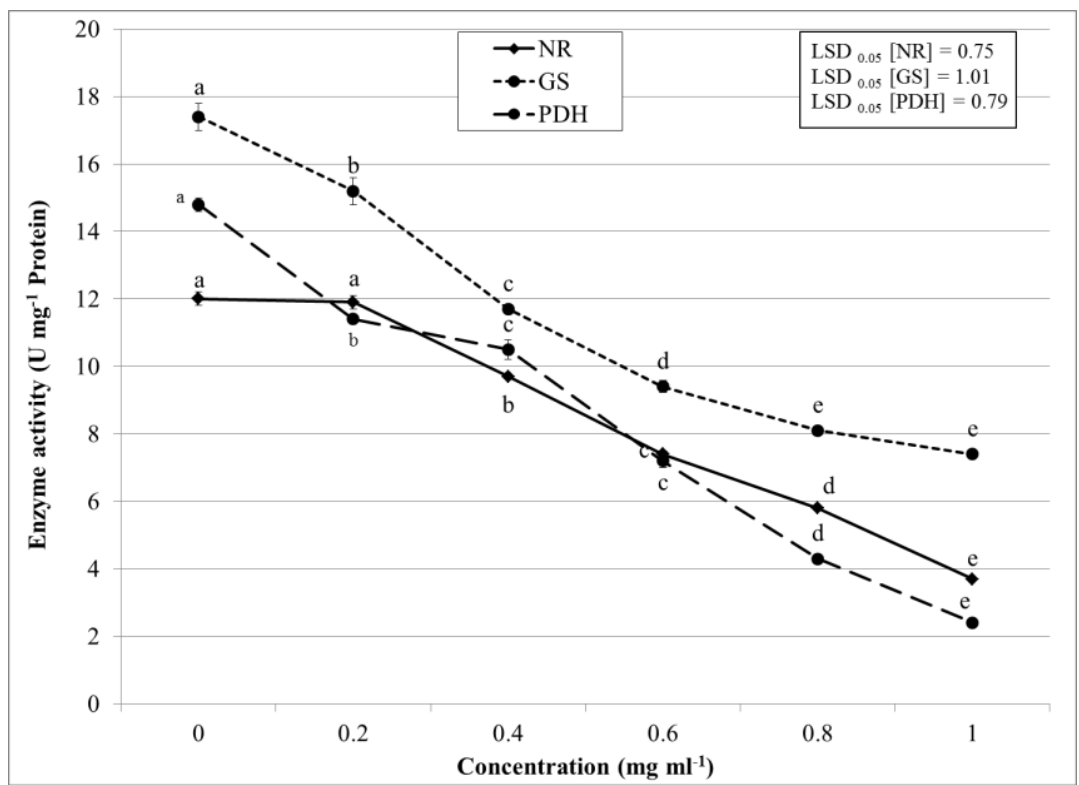

Fig. 6. Effect of Lupinus termis leaf extract on nitrate reductase (NR), glutamine synthetase (GS) and pyruvate dehydrogenase (PDH) activities of Portulaca oleracea leaves.

\section{Discussion}

The results in the present investigation show that $L$. termis leaf extract inhibited the germination of $P$. oleracea and the inhibition was concentrationdependent. The inhibition of seed germination may be due to the presence of allelochemicals at different levels in the L. termis leaf extract (Mohamadi and Rajaie 2009). In support, poor germination and seedling growth rate under allelochemical stress were observed in tomato (Sannigrahi and Chakrabortty 2005).

The protein content in $P$. oleracea leaves was reduced through treatment with L. termis extract. This reduction may be due to the effect of phenolic content in L. termis extract. It has been reported that many phenolic acids reduced the incorporation of certain amino acid into proteins and thus reduced the rate of protein synthesis (Baziramakenga et al. 1997). Also, various metabolic activities inhibited protein synthesis and stimulated its degradation (Mersie and Singh 1993). Ferulic acid as an allelochemical inhibited protein synthesis and reduced the incorporation of ${ }^{14} \mathrm{C}$ leucine. Maximum inhibition of protein synthesis by chlorogenic acid and vanillic acid was observed in leaves of lettuce (Lactuca spp.) (Mersie and Singh 1993). Protein synthesis was retarded after treatment with cinnamic acid as allelochemical (Einhellig 1996). The loss of proteins could be due to the transport of amino acids to the growing axes or respiratory loss, or it might result in the accumulation of free amino acids (Satyanarayana et al., 2011).

Egypt. J. Bot., 54, No. 2 (2014) 
Total lipid content was reduced in the $P$. oleracea leaves by application of the L. termis extract. Lipid is a major component in the membrane which has main role in a plant cell resistance in the proportional to environmental stress (Yordanov et al. 2003). Main changes will happen in lipid metabolism under conditions of stress (Benhassaine-Kesri et al., 2002). Mono galactosyl diglyceride the main glycol lipid in leaf, can be affected by stress (Yordanov et al., 2003; Gürsoy et al., 2013). In addition, lipid peroxidation was synchronized with increased stress (Yazici et al., 2007; Gürsoy et al., 2013).

Total soluble sugars content in the $P$. oleracea leaves was decreased after treatment with $L$. termis extract which may be due to requirement for energy at initial stages of seedlings growth. Also, the observed reduction of total soluble sugars may be due to the decline in the chlorophyll content by allelochemicals of the L. termis extract(s) (Kavitha et al., 2012).

On the other hand, the total free amino acid content increased with increasing concentration of the L. termis extract. The increase in free amino acid contents may be due to rapid hydrolysis of protein, which results in release of free amino acids. Similar results were reported in Egyptian senna (Cassia senna Mill.) seedlings (Al-Helal 1992) and chickpea (C. arietinum L.) (Mangal et al., 2013).

The endogenous $\mathrm{CaM}$ regulates a number of enzymes that have important functions in plant metabolism such as $\mathrm{Ca}^{2+}$-ATPase activity in a variety of cell compartment under stress (Zielinski, 1998). The present results show an increase in CaM of $P$. olercea leaves after treatment with $L$. termis extract. It seems likely that the increase in $\mathrm{CaM}$ synthesis enables plants to adapt the stress induced by allelochemicals in L. termis extract. Also, the induction of $\mathrm{CaM}$ in P. oleracea may be due to its contribution in the activation of antioxidant enzymes under allelochemicals stress. In support, $\mathrm{CaM}$ was found to stimulate the activity of plant catalase (Yang and Poovaiah, 2002) to remove $\mathrm{H}_{2} \mathrm{O}_{2}$ and thus prevents lipid peroxidation.

The present results show that treatment of the $P$. oleracea seedlings with the L. termis extract resulted in an increase of ABA content in leaves. It has been reported that $\mathrm{ABA}$ content increased in the xylem of roots and shoots in desert poplar (Populus euphraticai Oliv.) under stress conditions (Chang et al., 2006). It has been reported that stress causes enhancement of biosynthesis and accumulation of $\mathrm{ABA}$ and this enhancement can modulate physiological reaction in plant response to stress (Gómez-Cadenas et al., 1999). Also, it has been shown that the increase of ABA content under stress could be attributed to the synthesis of stress messenger ABA, which is possibly the result of feedback-stimulated expression of ABA biosynthetic gene (Xiong et al., 2001). ABA has been 
suggested to induce the gene expression of antioxidant enzymes and up regulate many stress responsive genes (Zhu, 2002; Gürsoy et al., 2012).

The content of IAA in the $P$. oleracea leaves was reduced after treatment with the L. termis extract. This is possibly due to the inhibitory effect of allelopathic compounds in lupin extract on its synthesis. In support, illustrated decline of IAA in roots of rice (Oryza spp.) seedlings by some allelochemicals (Yang et al., 2008).

The $\alpha$-amylase enzyme catalyzes the starch hydrolysis and hence its utilization for providing energy during seedling growth (Chong et al., 1994). The present results indicate an increase in the activities of $\alpha$-amylase and indole acetic acid oxidase in $P$. oleracea leaves after treatment with $L$. termis leaf extract. In contrast, $\alpha$-amylase of common barnyard grass (Echinochloa spp.) was inhibited through treatment with a methanolic extract of common jasmine (Jasminum officinale L.) leaves (Teerarak et al., 2012).

The activities of NR, GS and PDH were declined in the P. oleracea leaves by L. termis leaf extract. This is possibly could be due to the stress by allelochemicals in L. termis leaf extract. In support, it has been reported that NR activity was decreased by allelochemicals (Rui-xia, 2000). The reduction of NR activity in $P$. oleracea leaves by $L$. termis extract could be possibly attributed to the retarding effect of absorption and transport of nitrate from roots to leaves by the effect of allelochemicals in the L. termis extract (Baki et al., 2000). Increasing the inhibition of the tested enzyme activity with increasing of the $L$. termis extract concentration may be due to increasing content of allelochemicals which can interfere with the enzyme reaction. Reduced synthesis of enzymes is another possible reason of reduced enzymes activities. The reduction of GS and PDH under allelopathy may be due to protein oxidation through the free radicals produced by allelochemicals in $L$. termis leaf extract. Protein oxidation may result in modification of enzymes and their binding properties. Protein modification due to formation of protein bound carbonyl groups is selectively targeted and the sites and nature of oxidative modifications are still largely unknown (Job et al., 2005). Oxidized proteins undergo diverse structure and functional change in their hydrophobicity which makes the proteins more susceptible to proteolysis (Davies, 2005).

In conclusion, the leaves of L. termis (crop waste) expressed a satisfactory inhibitory allelopathic effect particularly at the higher concentration on $P$. oleracea. Such inhibition could be due to allelochemicals present in L. termis leaves. However, further experiments needed to isolate, identify and characterize the allelochemicals. Whether exploring of natural bioherbicides (allelochemicals) or through the application of cover crops with allelopathic properties, allelopathy will be promising science in sustainable agriculture systems in the future.

Egypt. J. Bot., 54, No. 2 (2014) 


\section{References}

Abdel-Monaim, M., Gabr, M., El-Gantiry, S., Shaat, M. and El-Bana, A. (2012) Bacillus megaterium, a new pathogen on lupine plants in Egypt. Journal of Bacteriology Research, (4) 24-32.

Al-Helal, A. (1992) Growth and protein content of Cassia senna L. seedlings. Journal of King Saud University, (4) 5-13.

AOAC, W.H. (1990) "Official Methods of Analysis". Association of Official Analytical Chemists, Arlington, VA.

Awad, N. (1994) Lipid content and antimicrobial activity of phenolic constituents of cultivated Portulaca oleracea L. Bulletin of Faculty of Pharmacy, Cairo University (32), 137-142.

Baki, G., Siefritz, F., Man, H.M., Weiner, H., Kaldenhoff, R. and Kaiser, W. (2000) Nitrate reductase in Zea mays L. under salinity. Plant, Cell \& Environment, (23), 515-521.

Barbosa-Filho, J.M., Alencar, A.A., Nunes, X.P., Tomaz, A.C., Sena-Filho, J.G., Athayde-Filho, P.F., Silva, M.S., Souza, M.F. and Da-Cunha, E.V.L. (2008) Sources of alpha-, beta-, gamma-, delta-and epsilon-carotenes: A twentieth century review. Revista Brasileira de Farmacognosia, (18), 135-154.

Baziramakenga, R., Leroux, G.D., Simard, R.R. and Nadeau, P. (1997) Allelopathic effects of phenolic acids on nucleic acid and protein levels in soybean seedlings. Canadian Journal of Botany, (75), 445-450.

Benhassaine-Kesri, G., Aid, F., Demandre, C., Kader, J.-C. and Mazliak, P. (2002) Drought stress affects chloroplast lipid metabolism in rape (Brassica napus) leaves. Physiologia Plantarum, (115) p: 221-227.

Bertin, C., Yang, X. and Weston, L.A. (2003) The role of root exudates and allelochemicals in the rhizosphere, Plant and Soil, (256), 67-83.

Bradford, M.M. (1976) A rapid and sensitive method for the quantitation of microgram quantities of protein utilizing the principle of protein-dye binding. Analytical Biochemistry, (72), 248-254.

Ceska, M., Hultman, E. and Ingelman, B. A. (1969) A new method for determination of $\alpha$-amylase. Experientia, (25), 555-556.

Chang, Y., Chen, S.L., Yin, W.L., Wang, R.G., Liu, Y.F., Shi, Y., Shen, Y.Y., Li, Y., Jiang, J. and Liu, Y. (2006) Growth, gas exchange, abscisic acid, and calmodulin response to salt stress in three poplars. Journal of Integrative Plant Biology, (48), 286-293.

Cheema, Z.A., Farooq, M. and Wahid, A. (2013) "Allelopathy: Current Trends and Future Applications". Springer, Verlag. 
Cheema, Z.A.,Iqbal, M. and Ahmad, R. (2002) Response of wheat varieties and some rabi weeds to allelopathic effects of sorghum water extract. International Journal of Agriculture and Biology, (4), 52-55.

Cheng, L.,Cheng, Z., liu, H., Zhang, H., Zhang, W., Du, Y., Wang, Y., Li, H., Ying, X. and Kang, T. (2011) Liquid chromatographic (LC) determination of four bioactive compounds in the Portulaca oleracea L. Journal of Medicinal Plants Research, (5), 6876-6880.

Chong, C., Bible, B.B., Hak-Yoon, J. and Pessarakli, M. (1994) "Germination and emergence". Dekker, New York.

D'Abrosca, B., Pacifico, S., Scognamiglio, M.; Tsafantakis, N., Pagliari, E., Monaco, P. and Fiorentino, A. (2013) Petrorhagiosides A-D, New $\gamma$-Pyrone Derivatives from Petrorhagia saxifraga Link. Helvetica Chimica Acta, (96), 1273-1280.

Darbyshire, B. (1971) Changes in indoleacetic acid oxidase activity associated with plant water potential. Physiologia Plantarum, (25), 80-84.

Davies, M.J. (2005) The oxidative environment and protein damage. Biochimica et Biophysica Acta (BBA)-Proteins and Proteomics, (1703), 93-109.

Einhellig, F.A. (1996) Interactions involving allelopathy in cropping systems. Agronomy Journal, (88), 886-893.

El-Rokiek, K. and Eid, R. (2009) Allelopathic effects of Eucalyptus citriodora on amaryllis and associated grassy weed. Planta Daninha, (27), 887-899.

El-Shora, H. and Abo-Kassem, E. (2001) Kinetic characterization of glutamate dehydrogenase of marrow cotyledons. Plant Science, (161), 1047-1053.

El-Shora, H.M. and ap Rees, T. (1991) Intracellular location of NADP+-linked malic enzyme in C3 plants. Planta, (185), 362-367.

Ferreira, M. and Reinhardt, C. (2010) Field assessment of crop residues for allelopathic effects on both crops and weeds. Agronomy Journal, (102), 1593-1600.

Gómez-Cadenas, A., Verhey, S.D., Holappa, L.D., Shen, Q., Ho, T.-H.D. and Walker-Simmons, M. (1999) An abscisic acid-induced protein kinase, PKABA1, mediates abscisic acid-suppressed gene expression in barley aleurone layers. Proceedings of the National Academy of Sciences, (96),1767-1772.

Gordon, S.A. and Weber, R.P. (1951) Colorimetric estimation of indoleacetic acid. Plant Physiology, (26),192.

Gürsoy, M., Balkan, A. and H., U. (2012) Ecophysiological responses to stress in plants: A General approach. Pakistan Journal of Biological Sciences, (15), 506-516.

Gürsoy, M., Balkan, A. and Ulukan, H. (2013) Bitkisel Üretimde Allelopati. U Ü Ziraat Fakültesi Dergisi, (27),115-122.

Hageman, R. and Reed, A. (1980) Nitrate reductase from higher plants. Methods in Enzymology, (69), 270-280.

Egypt. J. Bot., 54, No. 2 (2014) 
Hussain, F., Ahmad, B., Hameed, I., Dastagir, G., Sanaullah, P. and Azam, S. (2010) Antibacterial, antifungal and insecticidal activities of some selected medicinal plants of Polygonaceae. African Journal of Biotechnology, (9), 5032-5036.

Inderjit, D. (2003) Ecophysiological aspects of allelopathy. Planta, (217), 529-539.

James, J. and Bala, R. (2003) Allelopathy: How plants suppress other plants. IFAS, University of Florida, USA.

Job, C., Rajjou, L., Lovigny, Y., Belghazi, M. and Job, D. (2005) Patterns of protein oxidation in Arabidopsis seeds and during germination. Plant Physiology, (138),790-802.

Kavitha, P., Miller, A., Mathew, M. and Maathuis, F.J. (2012) Rice cultivars with differing salt tolerance contain similar cation channels in their root cells. Journal of Experimental Botany, (63), 3289-3296.

Khanh, T., Xuan, T. and Chung, I. (2007) Rice allelopathy and the possibility for weed management. Annals of Applied Biology, (151), 325-339.

Lim, Y. and Quah, E. (2007) Antioxidant properties of different cultivars of Portulaca oleracea. Food Chemistry, (103), 734-740.

Mangal, K.M., Bhat, J.L., Kumar, A. and Saini, P. (2013) Allelopathic effect of aqueous leaves extract of Moringa oleifera $\mathrm{L}$. on seedling growth of Cicer arietinum L. African Journal of Agricultural, (8),1028-1032.

Maqbool, N., Wahid, A., Farooq, M., Cheema, Z. and Siddique, K. (2013) In: "Allelopathy and Abiotic Stress Interaction in Crop Plants". Cheema Z.A., Farooq M., and Wahid A. (Ed.), Allelopathy, Springer-Verlag Berlin, Heidelberg, p: 451-468.

Mersie, W. and Singh, M. (1993) Phenolic acids affect photosynthesis and protein synthesis by isolated leaf cells of velvet-leaf. Journal of chemical ecology, (19), 1293-1301.

Miyanishi, K. and Cavers, P. (1980) The biology of Canadian weeds: 40. Portulaca oleracea L. Canadian Journal of Plant Science, (60), 953-963.

Mohamadi, N. and Rajaie, P. (2009) Effects of aqueous Eucalyptus (E. camadulensis Labill) extracts on seed germination, seedling growth and physiological responses of Phaseolus vulgaris and Sorghum bicolor. Research Journal of Biological Sciences, (4), 1292-1296.

Moor, S. and Stein, W.H. (1957) A modified ninhydrin Reagent for the photometric determination of amino acids and related compounds. Journal of Biological Chemistry, (211), 907-913.

Rhodes, D., Rendon, G. and Stewart, G. (1975) The control of glutamine synthetase level in Lemna minor L. Planta, (125), 201-211. 
Rui-xia, M. (2000) Effects of allelochemicals on activity of nitrate reductase. Journal of Environmental Sciences, (12), 125-128.

Sakai, N., Inada, K., Okamoto, M., Shizuri, Y. and Fukuyama, Y. (1996) Portuloside A, a monoterpene glucoside, from Portulaca oleracea. Phytochemistry, (42), 1625-1628.

Sannigrahi, A. and Chakrabortty, S. (2005) Allelopathic effects of weeds on germination and seedling growth of tomato. Allelopathy Journal, (16), 289-294.

Satyanarayana, B., Devi, P.S. and Arundathi, A. (2011) Biochemical changes during seed germination of Sterculia urens Roxb. Notulae Scientia Biologicae, (3),105-108.

Schwartz, E.R. and Reed, L.J. (1970) $\alpha$-Keto acid dehydrogenase complexes. XIV. Regulation of the activity of the pyruvate dehydrogenase complex of Escherichia coli. Biochemistry, (9), 1434-1439.

Singh, H., Batish, D.R. and Kohli, R. (2003) Allelopathic interactions and allelochemicals: new possibilities for sustainable weed management. Critical Reviews in Plant Sciences, (22), 239-311.

Southgate, D. (1991) "Determination of Food Carbohydrates". Elsevier, USA.

Teerarak, M., Laosinwattana, C., Charoenying, P. and Kato-Noguchi, H. (2012) Allelopathic activities of Jasminum officinale var. grandiflorum (Linn.) Kob.: Inhibition effects on germination, seed imbibition, and $\alpha$-amylase activity induction of Echinochloa crus-galli (L.) Beauv. African Journal of Biotechnology, (11), 7850-7854.

Ullah, N., Haq, I.U., Safdar, N. and Mirza, B. (2013) Physiological and biochemical mechanisms of allelopathy mediated by the allelochemical extracts of Phytolacca latbenia (Moq.) H. Walter. Toxicology and Industrial Health, (25), 1-7.

Weir, T., Park, S. and Vivanco, J. (2004) Biochemical and physiological mechanisms mediated by allelochemicals. Current Opinion in Plant Biology, (7), 472-479.

Weston, L.A. and Duke, S.O. (2003) Weed and crop allelopathy. Critical Reviews in Plant Sciences, (22), 367-389.

Wu, S., Chen, W. and Zhou, X. (1988). Solid phase enzyme-linked immunosorbent assays (ELISA) determine endogenous plant. Plant Physiology Communications, (5), 53-57.

Xiang, L., Xing, D.,Wang, W., Wang, R., Ding, Y. and Du, L. (2005) Alkaloids from Portulaca oleracea L. Phytochemistry, (66), 2595-2601.

Xiong, L., Gong, Z., Rock, C.D., Subramanian, S., Guo, Y., Xu, W., Galbraith, D. and Zhu, J.-K. (2001) Modulation of abscisic acid signal transduction and biosynthesis by an Sm-like Protein in Arabidopsis. Developmental Cell, (1), 771-781.

Yang, T. and Poovaiah, B. (2002) Hydrogen peroxide homeostasis: activation of plant catalase by calcium/calmodulin. Proceedings of the National Academy of Sciences (99), 4097-4102. 
Yang, Z., Wang, X., Gu, S., Hu, Z., Xu, H. and Xu, C. (2008) Comparative study of SBP-box gene family in Arabidopsis and rice. Gene, (407), 1-11.

Yang, Z., Zheng, Y. and Xiang, L. (2007) Study on chemical constituents of Portulaca oleracea. Journal of Chinese Medicinal Materials, (30), 1248-1250.

Yazici, I., Türkan, I., Sekmen, A.H. and Demiral, T. (2007) Salinity tolerance of purslane (Portulaca oleracea L.) is achieved by enhanced antioxidative system, lower level of lipid peroxidation and proline accumulation. Environmental and Experimental Botany, (61), 49-57.

Yordanov, I., Velikova, V. and Tsonev, T. (2003) Plant responses to drought and stress tolerance. Bulgarian Journal of Plant Physiology (Special issue), 187-206.

Zhao, S., Yu, H. and Zhang, M. (1988) Enzyme-linked immunosorbent assays (ELISA) for calmodulin. Acad. Med. Xuzhou., (8), 54-58.

Zhu, J.-K. (2002) Salt and drought stress signal transduction in plants. Annual Review of Plant Biology, (53), 247-273.

Zielinski, R.E. (1998) Calmodulin and calmodulin-binding proteins in plants. Annual Review of Plant Biology, (49), 697-725.

(Received 10/3/2014; accepted 27/8/2014) 


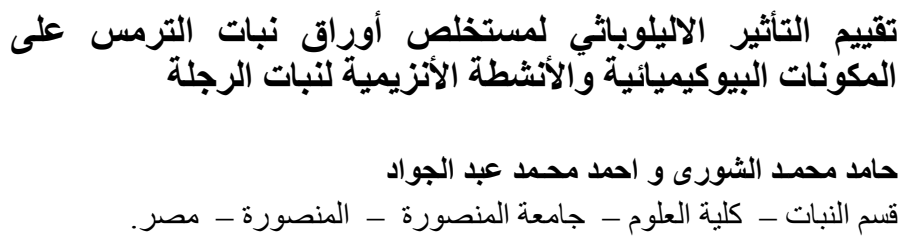

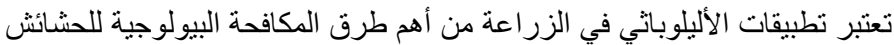

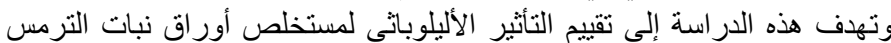

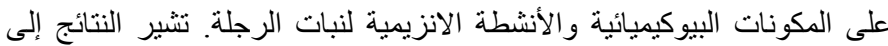

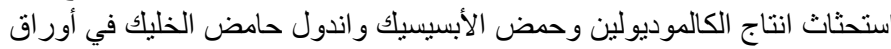

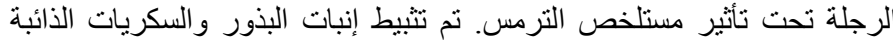

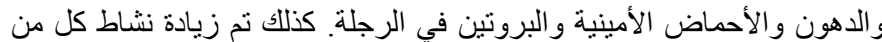

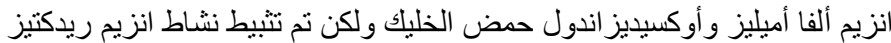

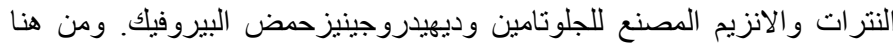
يمكن التوصية باستخدام مستخلص نبات الترمس كمبيد حيوي عشبي صديق للبيئة التئة 